\title{
Oral intermittent vitamin D substitution: influence of pharmaceutical form and dosage frequency on medication adherence: a randomized clinical trial
}

Jean-Pierre Rothen ${ }^{1,2^{*}}$ (D, Jonas Rutishauser ${ }^{3}$, Philipp N. Walter ${ }^{4}$, Kurt E. Hersberger ${ }^{1}$ and Isabelle Arnet ${ }^{1}$

\begin{abstract}
Background: To assess adherence to and preference for vitamin D substitution with different pharmaceutical forms and frequencies of administration.

Methods: A focus group of stakeholders aimed at preparing the design of an interventional, randomized, crossover study with $2 \times 2$ groups obtaining monthly or weekly vitamin D products in liquid or solid form for 3 months each. Dosage corresponds to cumulated amount of recommended $800 \mathrm{IU}$ daily (5.600 IU weekly / $24.000 \mathrm{IU}$ monthly). Main inclusion criteria were a vitamin D serum value $<50 \mathrm{nmol} / \mathrm{I}$ and age $\geq 18$ years. Primary endpoint was adherence, secondary endpoints were preferences and vitamin $D$ serum levels.

Results: The focus group reached consensus for preference of a monthly administration of solid forms to adults. Full datasets were obtained from 97 participants. Adherence was significantly higher with monthly (79.5-100.0\%) than weekly $(66.4-98.1 \%)$ administration. Vitamin D levels increased significantly $(p<0.001)$ in all participants. An optimal value of $>75 \mathrm{nmol} / \mathrm{l}$ was achieved by $32 \%$ after 3 months and by $50 \%$ after 6 months. Preferred formulation was solid form (tablets, capsules) for $71 \%$ of participants, and preferred dosage frequency was monthly for $39 \%$ of participants.
\end{abstract}

Conclusions: Monthly oral vitamin D in solid form lead to the highest adherence, and is preferred by the participants. However, only one third of study participants achieved values in the optimal range of $>75 \mathrm{nmol} / \mathrm{l}$ cholecalciferol using weekly or monthly administration providing an average daily cholecalciferol dose of $800 \mathrm{IU}$.

Trial registration: NCT03121593 | SNCTP000002251. Registered 30. May 2017,. Prospectively registered.

Keywords: Cholecalciferol, Oral intermittent treatment, Adherence, Preference, Formulation, Dosage frequency

\footnotetext{
* Correspondence: jp.rothen@unibas.ch

'Pharmaceutical Care Research Group, Department of Pharmaceutical Sciences, University of Basel, Petersplatz 14, Postfach 2148, CH-4001 Basel, Switzerland

${ }^{2}$ Nutrimed Ltd, Basel, Switzerland

Full list of author information is available at the end of the article
}

(c) The Author(s). 2020 Open Access This article is licensed under a Creative Commons Attribution 4.0 International License, which permits use, sharing, adaptation, distribution and reproduction in any medium or format, as long as you give appropriate credit to the original author(s) and the source, provide a link to the Creative Commons licence, and indicate if changes were made. The images or other third party material in this article are included in the article's Creative Commons. licence, unless indicated otherwise in a credit line to the material. If material is not included in the article's Creative Commons licence and your intended use is not permitted by statutory regulation or exceeds the permitted use, you will need to obtain permission directly from the copyright holder. To view a copy of this licence, visit http://creativecommons.org/licenses/by/4.0/ The Creative Commons Public Domain Dedication waiver (http://creativecommons.org/publicdomain/zero/1.0/) applies to the data made available in this article, unless otherwise stated in a credit line to the data. 


\section{Background}

An adequate supply of vitamin D can hardly be achieved with a usual diet and under normal exposition to sun light in temperate latitudes. Vitamin D deficiency occurs frequently, especially during winter months [1,2] and year around in elderly people who can only produce a reduced amount of vitamin D in their skin [3]. Other risk factors include dark skin (since melanin impairs the effect of UV-B radiation), overweight (because vitamin D is trapped in fatty tissue), lack of exercise, and cultural or religious dress codes (due to underexposure of the skin to sunlight) [4-7]. Hypovitaminosis D appears to play an important role in a number of extraskeletal diseases such as several autoimmune diseases $[8,9]$ or Alzheimer's and Parkinson's disease [10]. Vitamin D plays a key role in various physiological processes such as the regulation of brain development and activities in adulthood [11]. The serum value is considered the most significant indicator for vitamin D storage. Serum levels $<50 \mathrm{nmol} / \mathrm{l}$ indicate a deficiency and are associated in adults with secondary hyperparathyroidism, osteomalacia or osteoporosis, proximal limb muscle weakness, ataxia, and increased risk of falls, increased risk of fractures, or hampered effect of drugs used for osteoporosis [12]. Values $<25 \mathrm{nmol} / \mathrm{l}$ indicate a severe deficiency. Optimum values $>75 \mathrm{nmol} / \mathrm{l}$ are recommended in subjects with osteopenia, osteoporosis or fragility fractures, and in patients on treatment for osteoporosis [12], without exact definitions of the upper reference value [13]. Vitamin D can be supplemented in deficient individuals at every age for therapeutic or prophylactic purposes. However, recommendations differ. The US Institute of Medicine recommends a daily intake of $600 \mathrm{IU}$ for adults aged 19-59, $800 \mathrm{IU}$ for those aged > 60 and 1.500-2.000 IU vitamin D for those with severe vitamin D deficiency [14]. The maximum tolerable amount is $4.000 \mathrm{IU}$ vitamin $\mathrm{D}$ per day [14]. The upper limit for adults according to the Endocrine Society Clinical Practice Guideline is 10.000 IU vitamin D per day [8].

Due to a vitamin D half-life of about 2 months [15], intermittent weekly or monthly intake of cumulative doses of cholecalciferol achieves the same serum values as daily intake [16-18].

Recommended cumulative doses and frequencies of intermittent administration vary widely: $300.000 \mathrm{IU}$ annually [19], $50.000 \mathrm{IU}$ twice weekly $[13,20]$ or 20$25.000 \mathrm{IU}$ weekly [16, 21]. Compared with $24.000 \mathrm{IU}$ vitamin D monthly, the administration of $60.000 \mathrm{IU}$ monthly or additional $24.000 \mathrm{IU}$ calcifediol resulted in 25-hydroxyvitamin D levels above $75 \mathrm{nmol} / \mathrm{l}$ more often. However, the improvement of the lower extremity function did not differ among the treatment groups, while the incidence of falls differed significantly, with higher incidences in the 60.000 IU group and the 24.000 IU plus calcifediol group [22].

Pharmaceutical formulation can impact patient adherence [23]. In addition, the intake is more reliable with intermittent administration [24, 25]. In Switzerland, several oily and alcoholic solutions are currently commercially available for oral daily or intermittent use as well as newly formulated tablets for daily use.

This study aimed to explore which formulation and dosage frequency of vitamin D would ensure the highest adherence.

\section{Methods}

\section{Focus group}

A focus group is a moderated discussion with the aim of finding a consensus among experts on a specific issue [26]. Our focus group consisted of 10 individuals experienced with vitamin D administration, who are 5 healthcare professionals (2 family doctors, 2 community pharmacists, 1 home care nurse) and 5 patients. They rated the preferred pharmaceutical dosage form and dosage frequency separately for infants, adults and seniors on a yes / no / indifferent answer scale. Consensus was defined as unanimous, strong ( $\geq 90 \%$ identical votes) or firm ( $\geq 70 \%$ identical votes). Importance of reimbursement and physician's knowledge were answered with a 5 -point Likert scale (from -2 : not important to +2 : very important). Open discussion was facilitated in case of discordant voting before re-voting.

\section{Intervention study}

We performed an interventional, randomized, $2 \times 2$ groups cross-over study with administration of monthly or weekly vitamin D supplements in two liquid or two solid formulations for 6 months during winter time (Fig. 1). Study medications in liquid formulation were the $5 \mathrm{ml}$ bottle Vi-De $3^{\circ}$ monthly dose $(24.000 \mathrm{IU} / 5 \mathrm{ml}$ alcoholic solution) and the $30 \mathrm{ml}$ bottle including a graduated pipette Vitamin $\mathrm{D}_{3}$ Streuli $^{\bullet}$ weekly dose (5.600 IU/ $1.4 \mathrm{ml}$ oily solution). Solid medications consisted of the capsule Dekristol ${ }^{\oplus}$ monthly dose $(20.000 \mathrm{IU})$ and the tablet Dekristolvit ${ }^{\oplus}$ weekly dose $(5.600 \mathrm{IU})$. Each participant was randomized to a solid or liquid group with crossover to the other solid or liquid medication after 3 months. All strengths and dosages frequencies correspond to cumulative doses delivering on average the recommended 800 IU for daily intake for adults, except for capsules. Solid medication of vitamin D containing 24' $000 \mathrm{IU}$ were not commercially available. Participants were enrolled in 7 general practices in Basel. Informed consent was obtained from all participants. Primary endpoint was adherence (taking and timing), secondary endpoints were preferences and increase of vitamin D serum levels. 


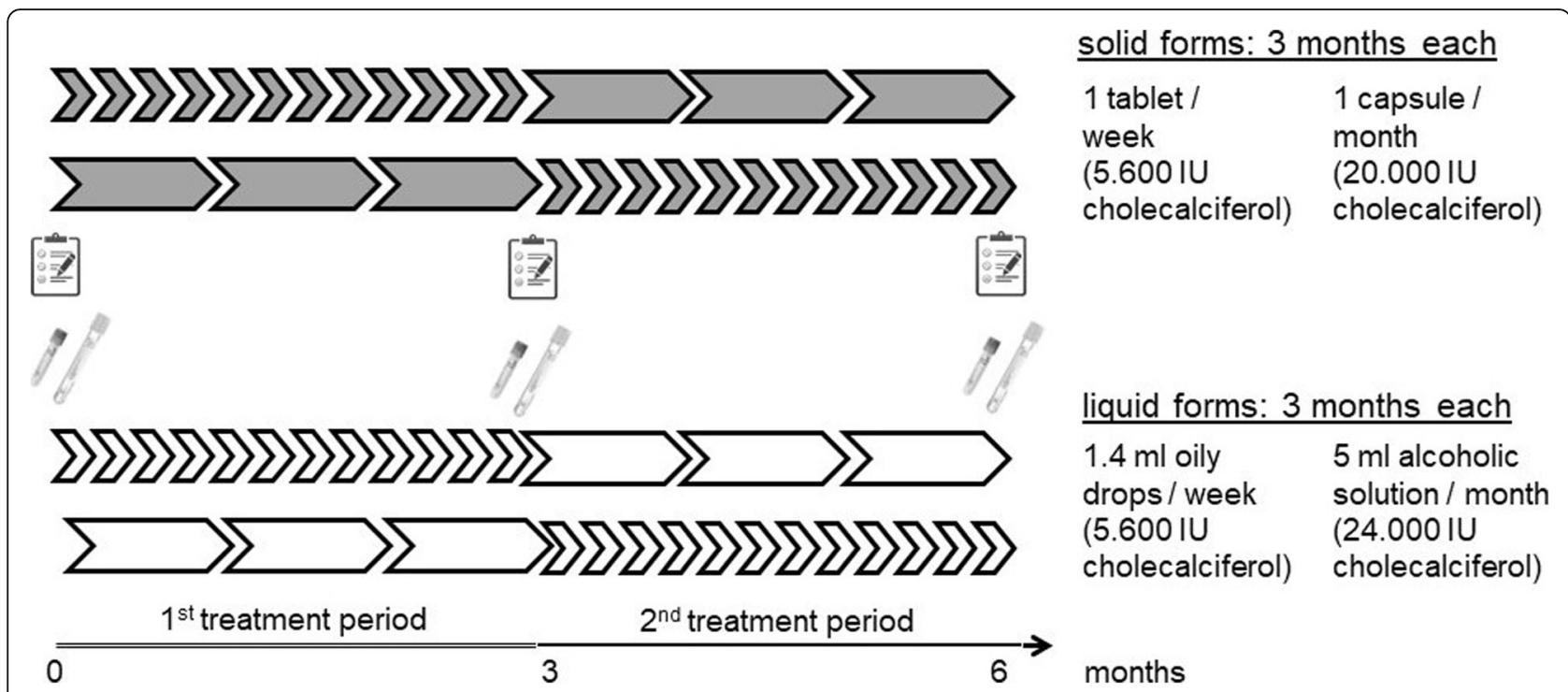

Fig. 1 Study design: Patients obtained vitamin D either as tablets (5.600 IU) and capsules (20.000 IU) or $1.4 \mathrm{ml}$ oily drops (5.600 IU) and $5 \mathrm{ml}$

alcoholic drinking solution (24.000 IU), for weekly and monthly administration over 3 months, respectively. Blood samples

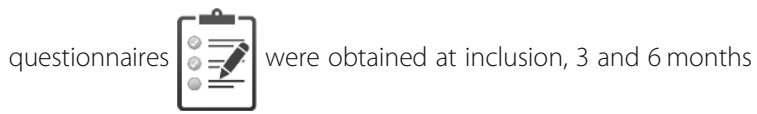

Main inclusion criteria were ambulatory patients $\geq 18$ years, vitamin D serum value $<50 \mathrm{nmol} / \mathrm{l}$ at baseline and at least one prescribed oral medication. Main exclusion criteria were hypercalcaemia and nephrolithiasis. Randomisation was achieved by removing a sealed envelope from a box containing $8 \mathrm{CRF}$ (case report form) for weekly or monthly administration in random order after $4 \times 4$ block randomization.

Adherence was assessed electronically. We reblistered solid forms into disposable punch cards with an electronic foil affixed on the back side [27]. For liquid forms, a Time4Med ${ }^{\mathrm{TM}}$ smart card [28] was handed out to participants who registered the intake by pushing the button. A time stamp (date and time) was generated for each removal of a tablet or a capsule from the punch card (for solid forms), or for pressing the button on the device (for liquid forms).

We calculated two adherence values from the time stamp series. Taking adherence expresses the percentage of doses taken and is calculated as [doses taken / doses prescribed] $\times 100$. Timing adherence expresses the percentage of doses taken within a preset time window of \pm $7.5 \%$, that is in an allowed interval of 6.475-7.525 days for weekly schedule, and of 27.75-32.25 days for monthly schedule. We performed a visual inspection of the returned bottles.
Serum levels of $25(\mathrm{OH})$ vitamin D (reference range $50-250 \mathrm{nmol} / \mathrm{l}$ ), parathyroid hormone (reference range $1.59-12.0 \mathrm{pmol} / \mathrm{l}$ ), calcium (reference range 2.10-2.55 $\mathrm{mmol} / \mathrm{l}$ ), phosphorus (reference range 0.74-1.52 $\mathrm{mmol} /$ 1), alkaline phosphatase (reference range 40-150 U/l), magnesium (reference range $0.66-1.07 \mathrm{mmol} / \mathrm{l}$ ), creatinine were measured at the Institute for Laboratory Medicine of the Solothurn hospitals using the Architect analysis system from Abbott $\mathrm{GmbH} \& \mathrm{Co}$, complete blood count using the Symex XN-Series from Sysmex Inc., at baseline, 3 and 6 months.

Three questions were asked about the intake of the specific product and one question about unexpected events during the prior 3 months: 1) How did you manage to take your medication in the past 3 months? (very good, good, bad, very bad); 2) How do you rate the pharmaceutical form of the past 3 months? (very pleasant, pleasant, unpleasant, very unpleasant); 3) How do you rate the frequency of [monthly / weekly] intake? (too frequent, ideal, too rare); 4) Have you noticed any unexpected events? (Yes (please specify), No). For evaluation of the preference, all answers were dichotomized in positive and negative statements.

During the final follow-up, general preferences were also asked: 5) Do you prefer a vitamin D preparation in solid or liquid form? (necessarily liquid, rather liquid, 
doesn't matter, rather solid, necessarily solid); 6) Which intake frequency is ideal for you? (daily, weekly, monthly, annually, doesn't matter); 7) Do you prefer [tablets or capsules? (for participants with solid forms) / alcoholic or oily drops? (for participants with liquid forms)]. Additionally, the question was asked whether the dosing pipette was an asset or a drawback (appropriate answers; doesn't matter).

Power calculation showed that 118 patients would suffice to detect a difference of $25 \%$ in timing adherence between solid and liquid forms with a $80 \%$ power. The statistical evaluation was carried out using SPSS $^{\circ}$ (IBM, version 25). The following statistical tests were used: Mann-Whitney U-test to compare different groups, Wilcoxon to compare the results of two time points, Friedman to compare three time points and Spearman to evaluate correlations. $p$-values $<0.05$ were considered significant. Arithmetical mean of Likert-Scale answers was calculated.

This study was prospectively registered and approved by the local ethics committee (EKNZ-Nr. 2017-00300).

\section{Results}

\section{Focus group}

Participants preferred unanimously tablets or capsules for adults and seniors, in a monthly frequency for adults and daily or weekly for seniors, especially those with multicompartment adherence aids (strong consensus). For infants, i.e. those who cannot be administered solid dosage forms, a weekly administration was unanimously preferred by the participants, with oily drops (strong consensus).

Reimbursement by health insurance was considered of moderate importance (mean +0.4 , range - from -2 to + 2). Physicians wanted to know if their patients were taking vitamin $\mathrm{D}$ (mean +1.5 , range - from 0 to +2$)$, even if they were not the prescribers, particularly in elderly people, for instance in cases of renal insufficiency or hypercalcaemia. This attitude was understandable for the other participants of the focus group.

\section{Intervention study}

A total of 106 patients were enrolled between October 2017 and April 2018, i.e. winter months in Basel. Nine patients dropped out due to protocol violations, including failure to initiate treatment or missing the 3-month control visit (three patients each), and study termination due to nausea, hospitalization, or death (one patient each). Ninety-seven complete datasets were available for evaluation (Table 1).

\section{Adherence related to dosage frequency}

Taking adherence was significantly higher during the first 3 months of treatment compared to the second 3 months, independently of the formulation $(99.0 \%$ vs. 94.7\%; $p=0.001$; data not shown). Taking and timing adherence were significantly higher with monthly administration compared to weekly administration, independently of the formulation (Table 2).

\section{Adherence related to pharmaceutical formulation}

Within a dosage frequency (weekly or monthly), the adherence did not differ significantly between the pharmaceutical formulation (Table 2). From the returned bottles with a graduated pipette, $28 \%$ contained too much or too little expected residual volume. All participants returning bottles with clearly too much residual solution achieved suboptimal serum values.

\section{Serum values}

Patient's baseline vitamin D values were similar in both solid and liquid preparations groups $(p=0.108)$. The vitamin $D$ values of all participants increased significantly in both treatment periods $(p<0.001)$ and with each pharmaceutical formulation (Table 1). After two treatment periods, the values of solid and liquid formulations were similar $(p=0.067)$.

Values in the reference range $>50 \mathrm{nmol} / \mathrm{l}$ were not reached by $29 \%$ of participants after 3 months and by $9 \%$ after 6 months of treatment, respectively. Values in the optimal range of $>75 \mathrm{nmol} / \mathrm{l}$ were reached by $18 \%$ of participants after 3 , and $37 \%$ of them after 6 months of treatment, respectively. No values above the reference range were observed. The highest value measured in the study was $144 \mathrm{nmol} / \mathrm{l}$.

Values in the optimal range of $>75 \mathrm{nmol} / \mathrm{l}$ were reached by $32 \%$ of the participants with the solid dosage after the first treatment period, by $50 \%$ after the second treatment period. In the participants who were treated with drops, the proportion was 7 and $26 \%$ respectively.

\section{Other biomarkers}

With treatment, serum parathyroid hormone levels [pmol/l] decreased significantly from 7.75 at baseline to 7.30 after the first treatment period and 7.19 after the second treatment period $(p=0.036)$. Similarly and as expected, mean serum phosphorus concentrations [mmol/ 1] increased under treatment from 1.51 (baseline) to 1.53 and $1.92(p<0.001)$, serum alkaline phosphatase [IU/l] decreased from 83 (baseline) to 81 and $76(p=0.001)$. Serum levels of all other biomarkers tested remained unchanged, e.g. mean serum calcium levels $[\mathrm{mmol} / \mathrm{l}]$ were 2.41 (baseline), 2.40 (first treatment period) and 2.43 (second treatment period).

\section{Adverse events}

Adverse reactions were not serious nor could they be associated with hypercalcaemia (Table 3). 
Table 1 Characteristics of the study population and vitamin D serum values at baseline and after 3 months' treatment periods. Values $>75 \mathrm{nmol} / \mathrm{l}$ are considered optimal

\begin{tabular}{|c|c|c|c|c|}
\hline & Patients on solid forms & Patients on liquid forms & p-value & $\begin{array}{l}\text { Total of } \\
\text { patients }\end{array}$ \\
\hline number $(\mathrm{n})$ & 42 & 55 & n.a. & 97 \\
\hline male gender [\%] & 45.2 & 40.0 & n.a. & 42.3 \\
\hline mean age [years] $\pm s$ & $63.1 \pm 11.6$ & $61.6 \pm 17.2$ & n.s. & $62.2 \pm 15.0$ \\
\hline mean weight $[\mathrm{kg}] \pm \mathrm{s}$ & $76.2 \pm 14.6$ & $77.0 \pm 16.5$ & n.s. & $76.6 \pm 15.6$ \\
\hline \multicolumn{5}{|l|}{$\begin{array}{l}\text { vitamin } D \text { serum } \\
\text { values mean } \pm s \\
{[\mathrm{nmol} / \mathrm{l}]}\end{array}$} \\
\hline baseline & $\begin{array}{r}33.5 \\
\pm 12.9\end{array}$ & $\begin{array}{l}29.9 \\
\pm 10.8\end{array}$ & 0.108 & $\begin{array}{r}30.9 \\
\pm 11.9\end{array}$ \\
\hline $\begin{array}{l}\text { after } 1^{\text {st }} \text { treatment } \\
\text { period }\end{array}$ & $\begin{array}{r}67.4 \\
\pm 19.4\end{array}$ & $\begin{array}{l}54.7 \\
\pm 14.5\end{array}$ & 0.042 & $\begin{array}{r}60.1 \\
\pm 17.8\end{array}$ \\
\hline $\begin{array}{l}\text { after } 2^{\text {nd }} \text { treatment } \\
\text { period }\end{array}$ & $\begin{array}{r}75.7 \\
\pm 20.9\end{array}$ & $\begin{array}{l}68.5 \\
\pm 18.6\end{array}$ & 0.067 & $\begin{array}{r}71.5 \\
\pm 19.8\end{array}$ \\
\hline
\end{tabular}

* $p$-value $<0.01$

** $p$-value 0.01

Table 2 Taking and timing adherence values (average) according to pharmaceutical forms (solid and liquid) and dosage frequency (weekly and monthly). Non-significance is marked with "n.s"

\begin{tabular}{|c|c|c|c|c|c|c|}
\hline & & $\begin{array}{r}\text { wee } \\
\text { administr }\end{array}$ & $\begin{array}{l}\text { kly } \\
\text { ation [\%] }\end{array}$ & administ & $\begin{array}{l}\text { thly } \\
\text { ation [\%] }\end{array}$ & $\mathrm{p}$-value \\
\hline & Taking Adherence & 98.1 & & 100.0 & & 0.013 \\
\hline ס) & Timing Adherence & 73.2 & 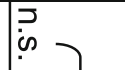 & 79.5 & 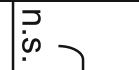 & 0.030 \\
\hline & Taking Adherence & 94.5 & ़ְ & 96.0 & $\vec{\rho}$ & 0.012 \\
\hline 흠 & Timing Adherence & 66.4 & 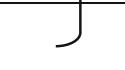 & 79.5 & J & 0.001 \\
\hline
\end{tabular}


Table 3 Listing of all reported unexpected events after 3 or 6 months of cumulative weekly or monthly oral treatment with 800 IU cholecalciferol/day (translated from Swiss German)

\begin{tabular}{|c|c|}
\hline Preparation & Unexpected event \\
\hline oily drops & fatigue, but also occurred before \\
\hline alcoholic drops & $\begin{array}{l}\text { possible fatigue, unclear whether } \\
\text { there is a connection }\end{array}$ \\
\hline oily drops & uncharacteristic abdominal pain \\
\hline oily drops & $\begin{array}{l}\text { shingles: under Vit D considerably } \\
\text { less frequent }\end{array}$ \\
\hline oily drops & less tired than usual \\
\hline alcoholic drops & $\begin{array}{l}\text { generally feels better under vitamin } \mathrm{D} \text {, } \\
\text { is better off in the morning }\end{array}$ \\
\hline oily drops & foot swelling left 1 week ago - now better \\
\hline oily drops & nervous, palpitations \\
\hline alcoholic drops & $\begin{array}{l}\text { weight loss } 7 \mathrm{~kg} \text { in } 2 \text { months } \\
\text { (patient report not validated) }\end{array}$ \\
\hline alcoholic drops & $\begin{array}{l}\text { feeling, I let more water than usual } \\
\text { (suspected diuretic effect) }\end{array}$ \\
\hline alcoholic drops & heat feeling, feverish, sleep problems \\
\hline alcoholic drops & had once cramp in the leg \\
\hline oily drops & less pain in the hand \\
\hline alcoholic drops & localized itching \\
\hline alcoholic drops & a little gas (flatulence) \\
\hline oily drops & $\begin{array}{l}\text { possibly more diarrhea } \\
\text { (developed over time) }\end{array}$ \\
\hline oily drops & $\begin{array}{l}\text { at the first } 3 \text { doses some nausea } \\
\text { after ingestion, spontaneously gone }\end{array}$ \\
\hline capsules & $\begin{array}{l}\text { approx. } 10 \text { days after the 1st ingestion } \\
\text { night sweat outbreak (one-time) }\end{array}$ \\
\hline oily drops & unique feeling of palpitations \\
\hline
\end{tabular}

\section{Preferences}

From the 97 participants who finished the study, all gave their preferences for each formulation taken during 3 months (tablet vs. capsule or alcoholic vs oily drops), Regarding management (question 1) coping was more often bad and very bad with weekly drops compared with weekly tablets $\left(\mathrm{Chi}^{2}=5.85 ; p=0.015\right)$. Regarding how pleasant the intake was (question 2), more participants indicated unpleasantness with liquid drops, independently of the frequencies $\left(\mathrm{Chi}^{2}=18.4 ; p<0.01\right)$. Regarding frequencies (question 3), fewer individuals estimated that monthly intake was too frequent, independently of the formulation $\left(\mathrm{Chi}^{2}=17.66 ; p<0.01\right)$.

A total of 29 patients (30\%) had no preference for any galenic formulation (question 5). Of the 68 remaining participants, 71\% $(n=48)$ opted for a solid form, and $29 \%(n=20)$ for a liquid form $(p<0.001)$. Half of the participants with prior experience of liquid formulations changed the sides. Only one patient who had taken capsules and tablets preferred the liquid forms.
When identical efficacy was assumed for different dosage frequencies (question 6), monthly intake was favored by $36.6 \%$ of the participants, weekly intake by $19.4 \%$, annual intake by $11.8 \%$ and daily intake by $8.6 \%$. Frequency did not matter for $23.7 \%$ of participants.

From the participants who had taken solid dosage forms, the type of formulation would not matter for $54 \%$; $34 \%$ preferred capsules, and 12\% tablets (question 7). Of those who had taken liquid dosage forms, the type of formulation did not matter for $24 \%$; $72 \%$ preferred drops (oily or alcoholic formulation). The dosing pipette for the oily solution was considered a drawback for 53\% of participants, and an advantage for $17 \%$ of them.

\section{Discussion}

We investigated which formulation and dosage frequency of oral vitamin D are best to promote high adherence in adult outpatients in need of a cholecalciferol substitution. We followed Swiss regulation on treatment recommendations and administered equivalents of 800 IU daily in liquid form (weekly oily drops of 5'600 IU or monthly alcoholic solution of 24'000 IU) and solid from (weekly tablet of 5'600 IU or monthly capsule of 20'000 IU). A higher adherence was observed with monthly administration, independently of the formulation. However, after 6 months of intake, a solid dosage form such as tablets or capsules was preferred together with monthly frequency. Thus, monthly administration of solid forms seems most suitable. Remarkably these results correspond to the conclusions of the focus group's discussion prior to study initiation. After three and 6 months of intake, all serum values of vitamin D had increased. However, optimal serum values were reached with solid substitution only by half of the participants and with liquid substitution by even only $26 \%$ of them. Potential reasons for this difference may be related to inaccurate dosing using the pipette, or a larger proportion of participants under solid forms who terminated the study in spring time. An influence of sun radiation cannot be excluded. On the other hand, the strength of the capsules was lower than intended. Therefore, differences in serum values between the two formulations need careful interpretation.

Some exceptions to a monthly administration of a solid form may exist for specific groups of patients. For example, patients with a multicompartment adherence aid may prefer a daily or a weekly administration. For infants who are not able to swallow capsules or tablets, liquid dosage form as non-alcoholic product may be preferable. Weekly or daily dosing seems easiest to manage for parents.

Vitamin D values increased in all treatment groups; however, 82 and $63 \%$ of the patients $63 \% \mathrm{x}$ did not reach an optimal value $>75 \mathrm{nmol} / \mathrm{l}$ after three and 6 months of 
intake, respectively. Our data clearly show that the administration of 800 cholecalciferol IU/day given as cumulative dose is not sufficient to treat profound vitamin $\mathrm{D}$ deficiency. These findings are in line with an earlier trial conducted with a similar number of participants [29]. A dosing scheme that reliably leads to sufficient $(>50 \mathrm{nmol} / \mathrm{l})$ or optimal $(>75 \mathrm{nmol} / \mathrm{l})$ vitamin $\mathrm{D}$ serum values without exceeding the maximum dosage of $4.000 \mathrm{IU}$ vitamin D per day as indicated by the Institute of Medicine [14] would be desirable.

The advantage of a dosing pipette was not evident to most study participants. The task of measuring the correct dose was not successfully achieved in $28 \%$ of patients, despite individual instructions from the investigating doctors. To avoid this kind of error, liquid solution could be manufactured to deliver an entire dose such as a drink ampule in analogy to a capsule or a tablet.

We considered the tolerance of $24 \mathrm{~h}$ for weekly intake which corresponds to a grace period of $15 \%$ appropriate for an adherence study. However, the acceptance limit for timing adherence with a range of $15 \%$ is discriminatory compared to more common 25\% [30]. For actual implementation outside an adherence trial, the intake interval of vitamin $\mathrm{D}$ is far less critical.

Our study has several strengths. First, instead of retrospective patient surveys, we used electronic devices to assess adherence. Thus, we obtained objective adherence values that are comparable over the different dosage frequencies without recall bias, which represents the main drawback of adherence questionnaires. Second, only patients with vitamin D deficiency of $<50 \mathrm{nmol} / \mathrm{l}$ were included in our study. Third, four preparations were compared which were commercially available in Switzerland or Germany. Thus, our results can be generalised and used to develop further formulations.

The study also shows some limitations. First, adherence values can be expected to be higher in volunteers who have been informed in detail of treatment objectives and are aware of monitoring procedure. Thus, the higher adherence measurement in the first treatment period could result from this Hawthorne effect. Second, the recommendation of $800 \mathrm{IU}$ cholecalciferol daily corresponds to the cumulative dose of $24.000 \mathrm{IU}$ per month [14]. No such solid product was commercially available in Switzerland nor in the surrounding countries (France, Germany, Italy, Austria). Thus, we used the closest dosage as possible which is $20.000 \mathrm{IU}$ in form of capsules. Consequently, we can assume that the measured effect of monthly vitamin D capsules would have been even more pronounced with 24.000 IU cholecalciferol. Third, we terminated the study after the recruitment of 106 instead of 128 participants end of April. This decision was made to avoid the influence of sunlight on individual serum vitamin $\mathrm{D}$ values. We preferred having a smaller sample size than biased laboratory findings.

\section{Conclusions}

An intermittent monthly oral therapy of vitamin D in solid form leads to the highest adherence, and is preferred by most adult participants. Although the cumulative dosage of $800 \mathrm{IU}$ cholecalciferol per day leads to an increase of vitamin D serum values in all participants, only a minority achieved values in the optimal range $>$ $75 \mathrm{nmol} / \mathrm{l}$ cholecalciferol. A dosing scheme that reliably leads to sufficient $(>50 \mathrm{nmol} / \mathrm{l})$ or optimal $(>75 \mathrm{nmol} / \mathrm{l})$ vitamin $\mathrm{D}$ serum values would be desirable. Physicians should investigate preferences in view of shared-decision making in the treatment choice.

\section{Supplementary information}

Supplementary information accompanies this paper at https://doi.org/10. 1186/s40360-020-00430-5.

Additional file 1. Questionnaire during the 3-months visit and the final examination: English translation. The questions were asked to the patients in German.

\begin{abstract}
Acknowledgments
We thank the investigators Dr. med. Karl Baier, Dr. med. Claus Diermayr, Dr. med. Karen Delport, Dr. med. Remigius Faesch, Prof. Alain Nordmann, Dr. med. Madeleine Rothen and Prof. Jonas Rutishauser for their scientific commitment in addition to their demanding duties as general practitioners.
\end{abstract}

\section{Authors' contributions}

JPR and IA participated collected and analyzed the data and participated in drafting the manuscript; JR participated clinical advisor of the study; PW participated in funding, investigation, and methodology; $\mathrm{KH}$ participated in funding and supervised the trial. All authors read and approved the final manuscript.

\section{Funding}

Funder: Abbott GmbH \& Co, Award Number: TL-CLIN-094, Grant Recipient: Philipp N Walter.

Funder: Verwaltungskommission des Fonds LOA IV/1, Award Number: NA, Grant Recipient: Kurt E Hersberger. The funder had no the role in the design of the study and collection, analysis, and interpretation of data and in writing the manuscript.

\section{Availability of data and materials}

The datasets during and/or analysed during the current study available from the corresponding author on reasonable request.

\section{Ethics approval and consent to participate}

The local ethics committee, Ethikkommission Nordwest- und Zentralschweiz, chair Prof. André Perruchoud, president of the EKNZ, granted full approval to carry out the study at seven general practices in Basel-City (EKNZ-Nr. 201700300). All participants signed written informed consent.

\section{Consent for publication}

Not applicable.

\section{Competing interests}

Jean-Pierre Rothen acknowledges that the work was performed as employee of Nutrimed Ltd. All other authors declare that they have no competing interests. 


\section{Author details}

${ }^{1}$ Pharmaceutical Care Research Group, Department of Pharmaceutical Sciences, University of Basel, Petersplatz 14, Postfach 2148, CH-4001 Basel, Switzerland. ${ }^{2}$ Nutrimed Ltd, Basel, Switzerland. ${ }^{3}$ Division of Endocrinology, Diabetes, and Metabolism, University Hospital, Basel, Switzerland. ${ }^{4}$ Solothurn Hospitals, Institute for Laboratory Medicine, Olten, Switzerland.

Received: 27 February 2020 Accepted: 2 July 2020

Published online: 11 July 2020

\section{References}

1. Adams JS, Hewison M. Update in vitamin D. J Clin Endocrinol Metab. 2010; 95(2):471-8.

2. Quarenghi MC, Aubry E, Aeberhard C, Ossola N, Marone C, Stanga Z. Vitamin D deficiency in the sunny corner of Switzerland. Praxis (Bern 1994). 2017;106(24):1323-30.

3. Hintzpeter B, Mensink GB, Thierfelder W, Muller MJ, Scheidt-Nave C. Vitamin D status and health correlates among German adults. Eur J Clin Nutr. 2008; 62(9):1079-89.

4. Kaddam IM, Al-Shaikh AM, Abaalkhail BA, Asseri KS, Al-Saleh YM, Al-Qarni $A A$, et al. Prevalence of vitamin $D$ deficiency and its associated factors in three regions of Saudi Arabia. Saudi Med J. 2017;38(4):381-90.

5. Abboud M, Rybchyn MS, Rizk R, Fraser DR, Mason RS. Sunlight exposure is just one of the factors which influence vitamin D status. Photochem Photobiol Sci. 2017;16(3):302-13.

6. Zittermann A, Ernst JB, Gummert JF, Borgermann J. Vitamin D supplementation, body weight and human serum 25-hydroxyvitamin $D$ response: a systematic review. Eur J Nutr. 2014;53(2):367-74.

7. Hardi I, Reinhard S, Conzelmann M, Kressig RW, Bridenbaugh SA. Vitamin D Level in Employees of a Swiss University Geriatric Hospital. Praxis (Bern 1994). 2018;107(12):633-40.

8. Scazzone C, Agnello L, Ragonese P, Lo Sasso B, Bellia C, Bivona G, et al. Association of CYP2R1 rs10766197 with MS risk and disease progression. J Neurosci Res. 2018;96(2):297-304

9. Bivona G, Agnello L, Ciaccio M. The immunological implication of the new vitamin D metabolism. Cent Eur J Immunol. 2018;43(3):331-4.

10. Bivona G, Lo Sasso B, lacolino G, Gambino CM, Scazzone C, Agnello L, et al. Standardized measurement of circulating vitamin $\mathrm{D}[25(\mathrm{OH}) \mathrm{D}]$ and its putative role as a serum biomarker in Alzheimer's disease and Parkinson's disease. Clin Chim Acta. 2019;497:82-7.

11. Bivona G, Agnello L, Bellia C, lacolino G, Scazzone C, Lo Sasso B, et al. NonSkeletal Activities of Vitamin D: From Physiology to Brain Pathology. Medicina (Kaunas). 2019:55(7):341. https://doi.org/10.3390/ medicina55070341.

12. Cesareo R, Attanasio R, Caputo M, Castello R, Chiodini I, Falchetti A, et al. Italian Association of Clinical Endocrinologists (AME) and Italian Chapter of the American Association of Clinical Endocrinologists (AACE) Position Statement: Clinical Management of Vitamin D Deficiency in Adults. Nutrients. 2018;10(5):546. https://doi.org/10.3390/nu10050546.

13. Holick MF, Binkley NC, Bischoff-Ferrari HA, Gordon CM, Hanley DA, Heaney $\mathrm{RP}$, et al. Evaluation, treatment, and prevention of vitamin D deficiency: an Endocrine Society clinical practice guideline. J Clin Endocrinol Metab. 2011; 96(7):1911-30.

14. Ross AC, Manson JE, Abrams SA, Aloia JF, Brannon PM, Clinton SK, et al. The 2011 report on dietary reference intakes for calcium and vitamin D from the Institute of Medicine: what clinicians need to know. J Clin Endocrinol Metab. 2011;96(1):53-8.

15. Jones G. Pharmacokinetics of vitamin D toxicity. Am J Clin Nutr. 2008:88(2): $582 s-6 s$

16. Noe $S$, Heldwein S, Pascucchi R, Oldenbuttel C, Wiese C, von Krosigk A, et al. Cholecalciferol 20000 IU once weekly in HIV-positive patients with low vitamin D levels: result from a cohort study. J Int Assoc Provid AIDS Care. 2017:16(4):315-20.

17. Ish-Shalom S, Segal E, Salganik T, Raz B, Bromberg IL, Vieth R. Comparison of daily, weekly, and monthly vitamin D3 in ethanol dosing protocols for two months in elderly hip fracture patients. J Clin Endocrinol Metab. 2008;93(9): $3430-5$

18. Takacs I, Toth BE, Szekeres L, Szabo B, Bakos B, Lakatos P. Randomized clinical trial to comparing efficacy of daily, weekly and monthly administration of vitamin D3. Endocrine. 2017;55(1):60-5.
19. Smith $H$, Anderson F, Raphael H, Maslin P, Crozier S, Cooper C. Effect of annual intramuscular vitamin $\mathrm{D}$ on fracture risk in elderly men and women--a population-based, randomized, double-blind, placebo-controlled trial. Rheumatology (Oxford). 2007:46(12):1852-7.

20. Wijnen H, Salemink D, Roovers L, Taekema D, de Boer H. Vitamin D supplementation in nursing home patients: randomized controlled trial of standard daily dose versus individualized loading dose regimen. Drugs Aging. 2015;32(5):371-8.

21. van Groningen L, Opdenoordt S, van Sorge A, Telting D, Giesen A, de Boer $\mathrm{H}$. Cholecalciferol loading dose guideline for vitamin D-deficient adults. Eur J Endocrinol. 2010;162(4):805-11.

22. Bischoff-Ferrari HA, Dawson-Hughes B, Orav EJ, Staehelin HB, Meyer OW, Theiler $\mathrm{R}$, et al. Monthly high-dose vitamin $\mathrm{D}$ treatment for the prevention of functional decline: a randomized clinical trial. JAMA Intern Med. 2016; 176(2):175-83.

23. Stewart KD, Johnston JA, Matza LS, Curtis SE, Havel HA, Sweetana SA, et al. Preference for pharmaceutical formulation and treatment process attributes. Patient Prefer Adherence. 2016;10:1385-99.

24. Dalle Carbonare L, Valenti MT, Del Forno F, Caneva E, Pietrobelli A. Vitamin D: Daily vs. monthly use in children and elderly-What is going on? Nutrients. 2017;9(7):652. https://doi.org/10.3390/nu9070652.

25. Bruyere O, Deroisy R, Dardenne N, Cavalier E, Coffiner M, Da Silva S, et al. A phase IV, two-armed, randomized, cross-over study comparing compliance with once-a-month administration of vitamin D3 to compliance with daily administration of a fixed-dose combination of vitamin D3 and calcium during two 6-month periods. Osteoporos Int. 2015:26(12):2863-8.

26. Kitzinger J. Qualitative research. Introducing focus groups. Bmj. 1995; 311(7000):299-302.

27. Boeni F, Hersberger KE, Arnet I. Multidrug punch cards in primary care: a mixed methods study on patients' preferences and impact on adherence. Front Pharmacol. 2014;5:220.

28. Arnet I, Rothen JP, Albert V, Hersberger KE. Validation of a novel electronic device for medication adherence monitoring of ambulatory patients. Pharmacy (Basel). 2019;7(4):155. https://doi.org/10.3390/pharmacy7040155.

29. Cavalier E, Fache W, Souberbielle JC. A randomised, double-blinded, placebo-controlled, parallel study of vitamin D3 supplementation with different schemes based on multiples of 25,000 IU doses. Int J Endocrinol. 2013;2013:327265

30. Zeller A, Schroeder K, Peters TJ. An adherence self-report questionnaire facilitated the differentiation between nonadherence and nonresponse to antihypertensive treatment. J Clin Epidemiol. 2008;61(3):282-8.

\section{Publisher's Note}

Springer Nature remains neutral with regard to jurisdictional claims in published maps and institutional affiliations.

Ready to submit your research? Choose BMC and benefit from:

- fast, convenient online submission

- thorough peer review by experienced researchers in your field

- rapid publication on acceptance

- support for research data, including large and complex data types

- gold Open Access which fosters wider collaboration and increased citations

- maximum visibility for your research: over $100 \mathrm{M}$ website views per year

At BMC, research is always in progress.

Learn more biomedcentral.com/submission 